\title{
A specific DNA hybridization probe for detection of Pasteurella piscicida
}

\author{
Jiang Zhao, Takashi Aoki* \\ Department of Fisheries, Faculty of Agriculture, Miyazaki University, Miyazaki 889-21, Japan
}

\begin{abstract}
A 692 base pair (bp) DNA fragment from the bacterial fish pathogen Pasteurella piscicida was cloned into pUC9 and used as a hybridization probe for the identification of $P$. piscicida. The radiolabeled probe hybridized with itself, but did not hybridize in colony hybridization with other fish pathogens (including Aeromonas hydrophila, A salmonicida, Edwardsiella tarda, Pseudomonas angulliseptica, Vibrio anguillarum and Yersinia ruckeri), or with other related organisms (Haemophilus influenzae, Pasteurella haemolytica, and P. multocida). Photobiotin-labeled probe hybridization detected $P$. piscicida chromosomal DNA by Southern and dot blot hybridizations. The radiolabeled probe directly detected $P$. piscicida on nitrocellulose filters smeared with infected kidney and spleen tissue of yellowtail Seriola quinqueradiata. The ${ }^{32} \mathrm{P}$-labeled DNA probe was capable of detecting $3.9 \mathrm{ng}$ of purified DNA and $10^{5}$ cells of $P$. piscicida. The cloned specific DNA probe can be used for rapid detection and identification of $P$. piscicida.
\end{abstract}

\section{INTRODUCTION}

Pasteurella piscicida is the causative agent of pseudotuberculosis in yellowtail Seriola quinqueradiata (Kimura \& Kitao 1971), one of the most important causes of mortality in cultured yellowtail. The identification of $P$. piscicida has been based on its morphological and biochemical characteristics. However, classification using these features is cumbersome and time-consuming. The different morphological and biochemical characteristics of the species of bacteria are prescribed by their genes. Recently, randomly cloned chromosomal DNA fragments and cloned genes encoding species-specific characteristics have been used as specific hybridization probes for rapid identification of organisms (Salyers et al. 1983, Nishibuchi et al. 1985, Carter et al. 1987, Mifflin et al. 1987). By using a species-specific DNA probe to a specific nucleotide sequence of chromosomal DNA from Vibrio anguillarum, we easily and rapidly identified $V$. anguillarum using colony hybridization (Aoki et al. 1989).

In the present study, we describe a species-specific DNA fragment of chromosomal DNA from Pasteurella piscicida which, by direct hybridization, specifically detects the causative agent in diseased marine fish.

\footnotetext{
- Addressee for correspondence
}

\section{MATERIALS AND METHODS}

Bacterial strains and plasmid. The bacterial strains used are listed in Table 1. Twenty-nine strains of Pasteurella piscicida were collected from diseased yellowtail in various areas of Japan and 1 strain from white perch, Morone americana, in the USA (Janssen \& Surgalla 1968). One $P$. piscicida strain (KG8601), isolated in 1986 from Kagoshima in Japan, was used for the cloning of its chromosomal DNA. Other fish pathogens (4) strains of Aeromonas hydrophila, 4 of A. salmonicida, 4 of Edwardsiella tarda, 2 of Pseudomonas anguilliseptica, 4 of Vibrio anguillarum, and 2 of Yersinia ruckeri), were used in testing the specificity of the probe, as were 1 strain each of Haemophilus influenzae, Pasteurella haemolytica and Pasteurella molutocida. Escherichia coli Strain JM103 (Maniatis et al. 1982) was used as the host for propagating the plasmid. The plasmid, pUC9 (Maniatis et al. 1982), was used for the cloning of $P$. piscicida chromosomal DNA.

Media and growth conditions. Pasteurella piscicida strains were cultured at $25^{\circ} \mathrm{C}$ in nutrient $(\mathrm{N})$ broth (beef extract: $15 \mathrm{~g}$; polypeptone: $10 \mathrm{~g}$ i NaCl: $5 \mathrm{~g}$; distilled water: $11 ; \mathrm{pH}$ : 7.2) supplemented with $0.3 \%$ yeast extract and $1.5 \% \mathrm{NaCl}$. The other Pasteurella species and Haemophilus influenzae were grown at $37^{\circ} \mathrm{C}$ in heart infusion broth (HI, Nissui Co. Ltd.) containing $5 \%$ 
Table 1. Bacterial strains used in this study

\begin{tabular}{|c|c|c|c|}
\hline Bacteria & Strain & Host & Source \\
\hline \multirow[t]{4}{*}{ Aeromonas hydrophila } & ATCC15467 & & Schubert (1974) \\
\hline & $A-10$ & & Wakabayashi et al. (1981) \\
\hline & $A-17$ & Eel & Nomura \& Aoki (1985) \\
\hline & $A-54$ & & Nomura \& Aoki (1985) \\
\hline \multirow[t]{4}{*}{ Aeromonas salmonicida } & ATCC14174 & Brooktrout & Kitao et al. (1985) \\
\hline & $\mathrm{N} 8004$ & & \\
\hline & OB8101 & Amago & \\
\hline & HR8101 & & \\
\hline \multirow[t]{4}{*}{ Edwardsiella tarda } & SA8318 & Flounder & This study \\
\hline & NG8407 & Trounder & \\
\hline & $\begin{array}{l}M Z 8401 \\
F=11-2\end{array}$ & Eel & \\
\hline & $\begin{array}{l}\text { E-11-2 } \\
\text { NCTC } 8143\end{array}$ & & Kilian \& Biberstein (1984) \\
\hline $\begin{array}{l}\text { Haemophilus influenzae } \\
\text { Fasteureláa haemolytica }\end{array}$ & NCTC9380 & & Carter $\{1984\}$ \\
\hline Pasteurella multocida & NCJC10322 & & Carter (1984) \\
\hline \multirow[t]{30}{*}{ Pasteurella piscicida } & $\mathrm{EH} H 218$ & & \\
\hline & KG8206 & & \\
\hline & KG8232 & & \\
\hline & MEP8215 & & \\
\hline & EH8306 & & \\
\hline & EH8310 & & \\
\hline & MZ8303 & & \\
\hline & MZ8309 & & \\
\hline & NG8304 & & \\
\hline & EH8405 & & \\
\hline & EH8411 & & \\
\hline & EHP84133 & & \\
\hline & EHP84135 & & \\
\hline & SA8406 & & \\
\hline & SA8407 & Yellowtail & This study \\
\hline & KG84305 & & \\
\hline & EHP85468 & & \\
\hline & EHP85477 & & \\
\hline & WKY 8575 & & \\
\hline & MZ8574 & & \\
\hline & MZ8575 & & \\
\hline & SA8514 & & \\
\hline & SA8516 & & \\
\hline & KG8601 & & \\
\hline & $\mathrm{EH} 8601$ & & \\
\hline & EH8606 & & \\
\hline & EH8610 & & \\
\hline & NG8609 & & \\
\hline & MZ8615 & & \\
\hline & Snieszko & White perch & Janssen \& Surgalla (1968) \\
\hline \multirow[t]{2}{*}{ Pseudomonas angulliseptica } & NCMB1949 & Eel & Nakajima et al. (1983) \\
\hline & ET -2 & LeI & Nakajima et al. (1983) \\
\hline \multirow[t]{4}{*}{ Vibrio anguillarum } & ATCC 19264 & & Baumann et al. (1984) \\
\hline & PT8341 & & Aoki et al. (1989) \\
\hline & PT -24 & Ayu & Kitao et al. (1983) \\
\hline & ET -1 & Eel & Kitao et al. (1983) \\
\hline \multirow[t]{2}{*}{ Yersinia ruckeri } & $11-4$ & Rainbow trout & Stave et al. (1987) \\
\hline & $11-29$ & 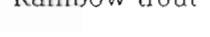 & Stave et al. (1987) \\
\hline
\end{tabular}

fildes extract (Oxoid Ltd.). Vibrio anguillarum strains were cultured at $25^{\circ} \mathrm{C}$ in $\mathrm{HI}$ broth containing $1 \% \mathrm{NaCl}$. Pseudomonas anguilliseptica and Aeromonas salmonicida were cultured at $20^{\circ} \mathrm{C}$ in $\mathrm{HI}$ and $\mathrm{N}$ broth, respectively. A. hydrophila, Edwardsiella tarda, and Yersinia ruckeri were cultured at $25^{\circ} \mathrm{C}$ in $\mathrm{N}$ broth. Escherichia coli was grown at $37{ }^{\circ} \mathrm{C}$ in Luria-Bertani broth (LB) (polypeptone: $10 \mathrm{~g}$; yeast extract: $5 \mathrm{~g}$; $\mathrm{NaCl} .5 \mathrm{~g}$; distilled water: 1 li pH 7.0) (Maniatis et al. 1982). Each medium also contained $1.5 \%$ agar to isolate organisms. 
Isolation of DNA. The chromosomal DNA of Pasteurella piscicida, Strain KG8601, and the fish-pathogens Aeromonas hydrophila A-10, A. salmonicida ATCC14174, and Vibrio anguillarum PT8341 were isolated by previously reported methods (Silhavy 1984). Plasmid DNA was prepared by the alkaline lysis method of Birmboim \& Doly (1979). Both isolated chromosomal DNA and plasmid DNA were purified by centrifugation to equilibrium in cesium chlorideethidium bromide gradients.

Molecular cloning of DNA probe. The chromosomal DNA of Pasteurella piscicida was digested with Hind III. The vector plasmid, pUC9, was also digested with the same enzyme and then dephosphorylated with bacterial phosphatase (Takara Shuzo Co. L.td, Kyoto, Japan). The digested DNA was mixed together and ligated with T4 ligase (Nippon Gene Co. Ltd, Osaka, Japan). The recombinant plasmids were transformed to Escherichia coli JM103, and transformants selected on L-agar (Maniatis et al. 1982) supplemented with $50 \mu \mathrm{g}$ $\mathrm{ml}^{-1}$ ampicillin and X-gal (5-bromo-4-chloro-3-indolyl$\beta$-D-galactopyranoside).

Labeling of DNA probe. A cloned DNA fragment with a molecular weight of about 0.7 kilobase (kb) was selected, at random, for use as the probe, and was isotopically labeled with $\left(\alpha-{ }^{32} \mathrm{P}\right) \mathrm{dCTP}$ (New England Nuclear Corp., Boston, USA) by nick translation (Rigby et al. 1977).

The DNA probe was labeled with photobiotin (Biotechnology Research Enterprises S.A. Pty Ltd), and the Blu GENE nonradioactive DNA detection system (Bethesda Research Laboratories, USA) was used. Probe DNA was mixed with equal volumes of photobiotin acetate in an Eppendorf tube, irradiated for 20 min with a $400 \mathrm{~W}$ lamp from a distance of $10 \mathrm{~cm}$, and diluted to $100 \mu \mathrm{l}$ with TE buffer $(10 \mathrm{mM}$ Tris $\mathrm{HCl}, 1 \mathrm{mM}$ EDTA, pH 8.0) followed by 100 ul 2-butanol. The mixture was centrifuged and the 2-butanol phase discarded. Photobiotin-labeled DNA was purified by 3 successive ethanol precipitations, and finally resuspended in TE buffer and stored at $-20^{\circ} \mathrm{C}$.

Southern and dot blot hybridization. For Southern blot hybridization, chromosomal DNAs of Pasteurella piscicida, Aeromonas hydrophila, A. salmonicida, and Vibrio anguillarum were cleaved by Hind III, and electrophoresed in $0.8 \%$ agarose gel at $80 \mathrm{~mA}$ for ca $3 \mathrm{~h}$. Electrophoresed gels containing digested DNAs were transferred to nitrocellulose filters $(0.45 \mu \mathrm{m}$, Schleicher \& Schuell Inc., FRG) using a transfer pyramid for Southern blotting (Southern 1975).

For dot blot hybridization, chromosomal DNA from Pasteurella piscicida was denatured by heating at $90^{\circ} \mathrm{C}$ for $5 \mathrm{~min}$ and diluted from $125 \mu \mathrm{g}$ to $1.95 \mu \mathrm{g} \mathrm{ml}^{-1}$ with $2 \times \mathrm{SSC}(1 \times \mathrm{SSC}=0.15 \mathrm{M} \mathrm{NaCl}+0.015 \mathrm{M}$ sodium citrate, $\mathrm{pH}$ 7.0). Samples of 250, 125, 62.5, 31.3, 15.7.
7.8 , and 3.9 ng of DNA were blotted on nitrocellulose filters.

Hybridization with ${ }^{32} \mathrm{P}$ labeled DNA probe was carried out on filters at $65^{\circ} \mathrm{C}$ for $36 \mathrm{~h}$ in $4 \times \mathrm{SSC}$ containing $10 \times$ Denhardt's solution (1\% Ficoll, $1 \%$ polyvinylpyrrolidone, $1 \%$ bovine serum albumin), $0.5 \%$ sodium dodecyl sulfate (SDS), and $1.5 \mathrm{mg} \mathrm{ml}^{-1}$ heat-denatured salmon-sperm DNA. Filters were washed with $2 \times \mathrm{SSC}$ $+0.1 \%$ SDS, dried, and subjected to autoradiography. Hybridization with the photobiotin-labeled probe was carried out at $42{ }^{\circ} \mathrm{C}$ for 12 to $18 \mathrm{~h}$ in a hybridization solution containing $45 \%$ formamide, $5 \times \mathrm{SSC}, 1 \times$ Denhardt's solution, 25 mM sodium phosphate ( $\mathrm{pH} 6.5$ ), $5 \%$ dextran sulfate, and $0.2 \mathrm{mg} \mathrm{ml}^{-1}$ heat-denatured salmon-sperm. After hybridization, the probe-target DNA hybrid was detected with conjugate dyes of the Blu GENE (Bethesda Research Laboratories) streptauidin-alkaline phosphatase

Colony hybridization. The organisms were inoculated onto autoclaved, gridded nitrocellulose filters (Toyo Roshi Co. Ltd, Japan) overlayed on an agar plate. After incubation, the filter was removed from the plate and treated with $\mathrm{NaOH}$, neutralized, baked, and hybridized with probe DNA. Hybridization reactions were carried out by the method of Grunstein \& Hogness (1975).

The minimum number of Pasteurella piscicida (Strain KG8601) cells detected was determined by hybridization with the same probe. Bacterial cells diluted 10 -fold from $10^{2}$ to $10^{8}$ were spotted on a nitrocellulose filter. DNA hybridization was then performed as described by Grunstein \& Hogness (1975).

Detection of Pasteurella piscicida in fish. Nineteen diseased and 3 healthy Seriola quinqueradiata were obtained from an experimental fishery station. These fish were dissected and examined to determine whether nodules of kidney and spleen, characteristic of the pseudotuberculosis, were present in the kidney and spleen of fish. Kidney and spleen tissue from each fish was sampled using a platinum loop and smeared onto nitrocellulose filters. Hybridization was then carried out with the same probe and by the same method as used in the colony hybridization procedure. At the same time, the causative agent was isolated on agar media and identified.

Restriction sites and nucleotide sequence of the probe. A cloned DNA fragment of Pasteurella piscicida, which was chosen at random and used as the probe, was digested by various endonucleases: AvaII, BamHI, EcoRI, HapII, HinclI, HindIII, Hinfl, Hpal, RsaI, SaII, Sau3AI, SmaI, TaqI, and Xhol (Takara Shuzo Co. Ltd, Nippon Gene Co. Ltd, Japan). Nucleotide sequences of this cloned DNA fragment were determined using pUC9 by the dideoxy method of Hattori et al. (1985). 




RESULTS

\section{Screening of DNA probe}

The molecular weights of the cloned DNA fragment obtained from 14 recombinant plasmids ranged from 0.4 to $4.0 \mathrm{~kb}$. A cloned DNA fragment with a molecular size of about $0.7 \mathrm{~kb}$ was chosen as the probe for experi.ments.

\section{Specificity of DNA probe}

The specificity of the $0.7 \mathrm{~kb}$ fragment was verified by Southern blot hybridization with chromosome DNAs of various fish pathogens. The radio- and photobiotinlabeled probes of the $0.7 \mathrm{~kb}$ fragment only hybridized with themselves. Probe DNA did not hybridize with chromosomal DNA from other tish pathogens tested (Fig 1).
Fig. 1. Southern blot hybridization of ${ }^{32} \mathrm{P}$ labeled cloned DNA fragment from Pasteurella piscicida with chromosomal DNAs of various fish pathogens. Panel. 1: agarose gel electropherogram of chromosomal DNAs digjested by HindII. Panel 2: autoradiogram of a nitrocellulose filter blotted with DNA from Panel 1 and probed with ${ }^{32} \mathrm{P}$ labeled cloned DNA of $P$ piscicida. Lane A: standard molecular size of $A$ DNA digested by HindIII; Lane B chromosomal DNA of $P$. piscicida; Lane C chromosomal DNA of Vibrio anguillarum: Lane D: chromosomal DNA of Aeromonas salmonicida; Lane E: chromosomal DNA of A. hydrophila
Further colony hybridization experiments were carried out to determine the specificity of the $0.7 \mathrm{~kb}$ fragment. Four colonies of different strains of Pasteurella piscicida and 1 of Escherichia coli (carrying the recombinant plasmid contained the $0.7 \mathrm{~kb}$ fragment from $P$. piscicida) hybridized with the ${ }^{32}$ P-labeled probe (Fig. 2). Others, i.e., Aeromonas hydrophila, A. salmonicida, Edwardsiella tarda, Pseudomonas anguilliseptica, Vibrio anguillarum, and Yersinia ruckeri did not hybridize (Fig. 2). No cross hybridization was seen between the probe and closely related Haemophilus influenzae, Pasteurella haemolytica, and P. multocida (Fig. 3).

Fig. 4 shows that the probe hybridized, not only with 29 strains of Pasteurella piscicida isolated from Seriola quinqueradiata cultured in various districts of Japan, but also with the 1 strain of $P$. piscicida isolated from white perch, Morone americana, in the USA. (Janssen \& Surgalla 1968). Photobiotin-labeled probe DNA used for colony hybridization was unsuccessful due to the high background it produced. 
Fig. 2. Colony hybridization of ${ }^{32}$ P-labeled cloned DNA fragment from Pasteurella piscicida with chromosomal DNA of various fish pathogens. DNA samples of bacterial strains located above numbers. 1 to 4: Vibrio anguillarum, 5 to 8: Aeromonas hydrophila, 9 to 12: A. salmonicida: 13 to 16: Edwardsiella larda; 17 to 20: Pasteurella piscicida; 21 to 22 Yersinia ruckeri; 23 to 24: Pseudononas anguilliseptica; 25: Escherichia coli JM103; 26: E. coli JM103 carrying recombinant pUC9-0.7 kb fragment from P. piscicida

\section{Quantitation of DNA and bacteria containing probe}

The sensitivity of the probe technique was determined by dot blot hybridization with radio- and photobiotin-labeled probe DNA. The ${ }^{32} \mathrm{P}$ labeled DNA probe detected 3.9 to $250 \mathrm{ng}$ of purified DNA in Pasteurella piscicida. The same amounts of DNA were detected by photobiotin-labeled probe DNA. Again, there was no hybridization with chromosomal DNAs of the other fish pathogens, Aeromonas hydrophila, A. salmonicida and Vibrio anguillarum (Fig. 5).

The number of Pasteurella piscicida cells detectable by the probe was also determined by colony hybridization using radiolabeled probe DNA and was from $10^{5}$ to $10^{8}$ cells (Fig. 6).

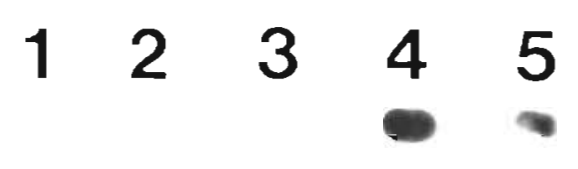

Fig. 3. Colony hybridization of ${ }^{32}$ p-labeled cloned DNA fragment from Pasteurella piscicida with closely related pathogens. 1: Pasteurella multocida NCTC10322; 2: P. haemolytica NCTC9380; 3: Haemophilus influenzae NCTC8143; 4: Pasteurella piscicida KG8601; 5: P. piscicida Snieszko

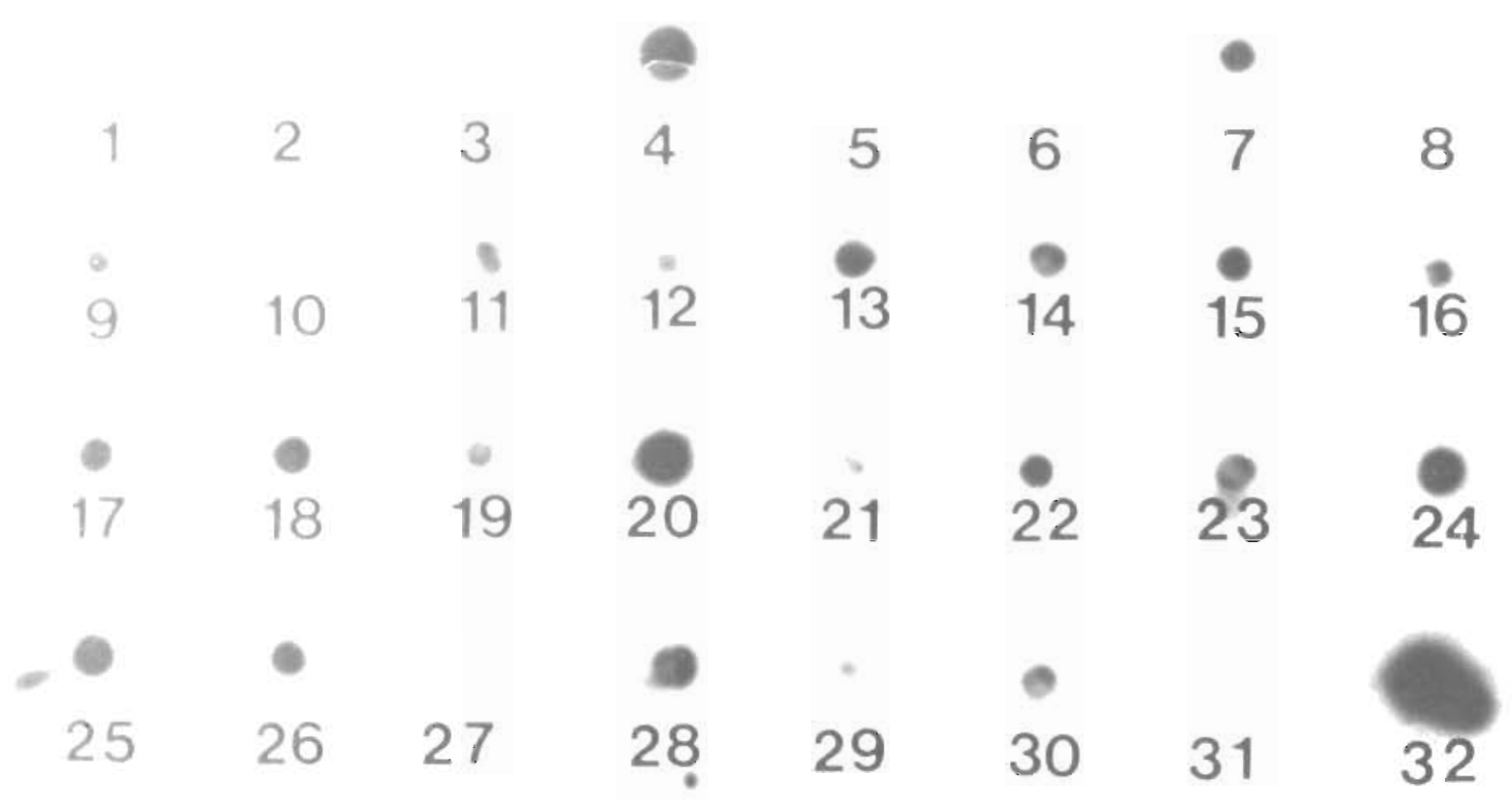

Fig. 4. Colony hybridization of ${ }^{32}$ P-labeled cloned DNA fragment from Pasteurella piscicida with different strains of $P$. piscicida isolated from various areas. 1 to 30 (except 24): different strains of $P$. piscicida isolated from diseased Seriola quinqueradiata from various locations in Japan; 24: strain of $P$. piscicida isolated from white perch, Morone americana, in the USA; 31: Escherichia coli JM103; 32: E. coli JM103 carrying recombinant pUC9-0.7 kb fragment from $P$ piscicida 
Panel 1

A
B
C
D

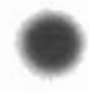

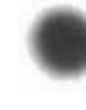
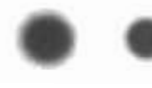

250

125

$$
\text { (ng DNA) }
$$
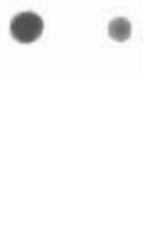

(ng DNA)

Fig. 5. Dot blot hybridization of radio- and photobiotin-labeled probe with chromosomal DNAs of various tish pathogens. Panel 1: hybridization of ${ }^{32}$ P-labeled cloned fragment DNA from Pasteurella piscicida. Panel 2: hybridization of photobiotin-labeled fragment DNA from $p$, piscicida. Lane A: chromosomal DNA of Vibrio anguillaruni; Lane B: chromosomal DNA of $P$. piscicida, Lane C: chromosomal DNA of Aeromonas hydrophila; Lane D: chromosomal DNA of A. salmonicida
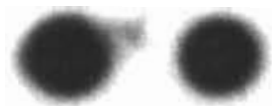

$10^{8}$
$10^{7}$



$10^{5}$
$10^{4}$

\section{Analysis of DNA Probe}

Fig. 7 illustrates the endonuclease restriction sites and the nucleotide sequences of cloned DNA fragment of Pasteurella piscicida, (i.e., the probe). The cloned DNA fragment had single HapII, HindIII, and Tagl sites, and double sites for Rsal; there were no restriction sites for the other endonucleases, i.e., Avall, BamHI, EcoRI, HincII, HinfI, HpaI, PstI, Sall, Sau3AI, SmaI, and XhoI. The fragment contained 692
Panel 2

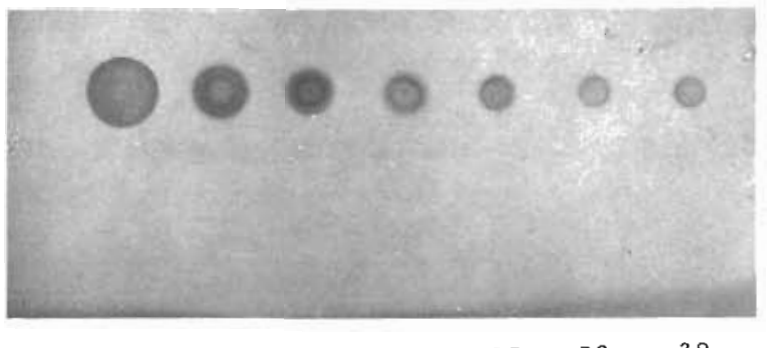

( ng ONA)
As of various tish patho
hybridization of photo
B: chromosomal DNA
DNA of $A$. salmonicida

Fig. 6. Minimum number of of Pasteurella piscicida cells detectable using ${ }^{32} \mathrm{P}$. labeled DNA fragment
Fig. 7. Restriction sites and nucleotide sequence in the 692 base pair fragment of DNA from Pasteurella piscicida (the probe) base pairs $(b p)$ and the guanine + cytosine $(G+C)$ content was $39.2 \%$.

\section{Detection of Pasteurella piscicida in clinical specimens}

All filters from diseased yellowtail proved positive, both by radiolabeled probe and by culture for $P_{a s-}$ teurella piscicida. Some hybridizations results are

\footnotetext{
Hind III

A.AGCTTGTAGCTCTTGTGGAGTAATGCTGACAGAAGAACAATAGCCAGECTTTGCGTGCCAGS TATCTCAACCTGAAATAGAAAACTGCGGCCTAGAGCTCACTTTTAGCCCCTCATGCTCGCTAN TTTAGCGGGCAATTTTATTTTATATCACTACAATACATATRTATTGGCCATATCATGAGT HaD II AAACACAGCTAGAAAAAAGA AGAGAAACCACAAAGAAATGGCGTCCGGTTCAGCTTCAGTGC TTTTGATAGCTATGAGCAATATGAACACATGATATGTCATCAGTGTTAAATGCCAATTGATAC TGCACCACCAAAGATCACGATGAAGAAATAACACCAATTTATCAATATCTTATGATAAGTTYG GTGACACA.TCGACTACTGCATTCAAATTACATGAAGTATTAATCTCGCTTGCTCATTAGCAGA Rsa I GCGAGATGGTACATGACATACTAACAGTGATATGCATGTGTCCTAGAGCCACCAAACTCATCT TTAATAAAGATGAGCTTGGAAAAATATCTCACGCACTGTGGCGATAACATCACCACCAATCAA Rsa I ATAGAGTGTATAGAAAAAATGTTCGCTTGCGGTA CCAGCAAAGTGGGCAGTAAGCACTACGE ATGTGAAAACCCTTATTGTGAGCACCGCAAAGTCATCTATAACTCTTGTAAGAGTA
} 


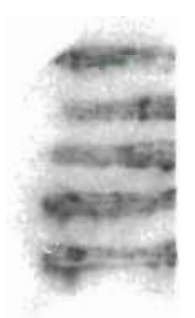

1
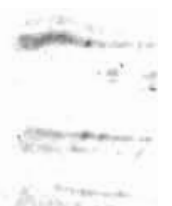

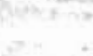

Fig. 8. Autoradiogram of ${ }^{32}$ P-labeled cloned DNA fragment from Pasteurella piscicida hybridized on nitrocellulose filter with smeared kidney and spleen tissues from diseased (i.e., 1 to 6) and healthy ( 7 to 9) Seriola quinqueradiata. For each yellowtail Smears 1 to 5 represent kidney tissue, Smear 6 to 9 spleen tissue
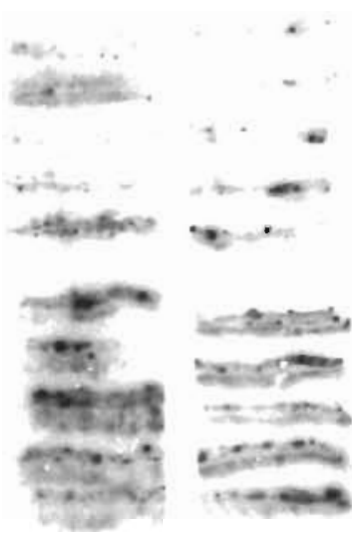

2
3

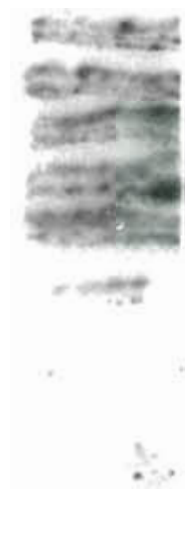

4 5 shown in Fig. 8. The hybridization signal strength appeared to be a function of pathogen concentration in tissues. Healthy fish proved negative both by the probe and culture techniques.

\section{DISCUSSION}

A 692 bp fragment of chromosomal DNA from $P a s-$ teurella piscicida was cloned in the pUC9 plasmid and used as a probe for detecting $P$. piscicida. The probe only hybridized with itself. There was no hybridization with any other tested fish pathogens or with closely related organisms. The 692 bp nucleotide sequence differed from any of the sequences in the nucleotide sequence library of GENAS (Kuhara et al. 1984).

The probe was successfully used to detect Pasteurella piscicida on filters smeared with kidney and spleen tissues from diseased Seriola quinqueradiata.
All smears from diseased yellowtail yieled positive reactions, the strength of reaction apparently being related to the number of $P$. piscicida cells in the smear. We did not determine the detecting limit of the filter hybridization procedure for the pathogen, but we think that it is lower than the $10^{5}$ cells per sample detected by the direct hybridization method in this study. This method allowed us to rapidly detect and identify $P$. piscicida in infected tissues and to rapidly identify colonies of the pathogen on culture plates.

The photobiotin-labeled probe used in these experiment was successful in detecting the chromosomal DNA of Pasteurella piscicida by dot blot hybridization. However, the photobiotin-labeled probe could not be used to detect $P$. piscicida by colony hybridization. In colony hybridization, some component of the bacterial cells on the nitrocellulose filter appeared to bind, non-specifically, with the coloring reagents of the detection system, thus resulting in unacceptably high background signals. 
The colony hybridization technique is more easily and quickly applied than the dot blot hybridization method. However, radiolabeled probes are generally unacceptable for routine clinical use and further development of detection procedures based on nonisotope labeling is, therefore, still required.

Acknowledgements. This research was supported in part by a Grant-in-Aid from the Ministry of Education. Science and Culture (625660199) of Japan. We thank Professor Tadatoshi Kitao for his useful discussions and valuable suggestions.

\section{LITERATURE CITED}

Aoki, I S. Egusa, K. Kimura, Watanabe, T (1971). Detection of $\hat{K}$ factors in naturaiiy occurring Aeromonas saimonicida strains. Appl. Microbiol. 22: 716-717

Aoki, T., Hirono, I., Castro, T D., Kitao, I (1989). Rapid identification of Vibrio anguillarum by colony hybridization. J. appl. Ichthyol. 5: 67-73

Baumann, P., Farniss, A. L., Lee, Lee J. V (1984). Genus I, Vibrio Pacini 1854, 411 AL Bergey's manual of systematic bacteriology, Vol. I. Williams \& Wilkins, Baltimore London, p. $518-538$

Birnboim, H. C., Doly, J. (1979). A rapid alkaline extraction procedure for screening recombinant plasmid DNA. Nucleic Acids Res. 7: 1513-1523

Carter, G. L., Towner, K. J., Slack, R. C. (1987). Rapid detection of a specific trimethoprim resistance gene using a biotinylated DNA probe. J. Antimicrob. Chemother. 20 . 335-341

Carter, R. R. (1984). Genus I. Pasteurella Trevisan 1887, 94, AL Nom. cons. Opin. 13, Jud. Comm. 1954, 153. Bergey's manual of systematic bacteriology, Vol. I. Williams \& Wilkins, Baltimore, London, p. 552-557

Grunstein, M., Hogness, D. S. (1975). Colony hybridization: a method for the isolation of cloned DNAs that contain a specific gene. Proc. natn. Acad Sci. U.S.A. 72: 3961-3965

Hattori, M., Hidaka, S., Sakaki, Y (1985). Sequence analysis of a Kpnl family member near the $3^{\prime}$ end of human $\alpha$ globin gene. Nucleic Acids Res. 13: 7813-7827

Janssen, W. A., Surgalla, M. J. (1968). Morphology, physiology, and serology of a Pasteurella species pathogenic for white perch. J. Bact. 96: 1906-1910

Kilian, M., Biberstein, E. L. (1984). Genus II. Haemophilus Winslow, Broadhurst, Buchanan, Krumwiede, Rogers and Smith 1917, 561, AL Bergey's manual of systematic bacteriology, Vol. I. Williams \& Wilkins, Baltimore, London, p 558-569

Kimura, M., Kitao, T. (1971). On the etiological agent of bacterial tuberculoidosis of Seriola. Fish Pathol. 6: 8-14

Kitao, T., Aoki, T., Fukudome, M. Kawano, K., Wada, Yo.

Responsible Subject Editor Dr T Evelyn, Nanaimo, B.C., Canada
Mizuno, Y. (1983). Serotyping of Vibrio anguillarum isolated from diseased freshwater fish in Japan. J. Fish Dis. 6: $175-181$

Kitao, T., Yoshida, T., Aoki, T, and Fukudome, M. (1985). Characterization of an atypical Aeromonas salmonicida strain causing epizootic ulcer disease in cultured eel. Fish Pathol. 20: 107-114

Kuhara, S., Matsuo, F., Futamura, S., Fujita, A., Shinohara, T. Takagi, T., Sakaki, Y (1984). GENAS: a database system for nucleic acid sequence analysis. Nucleic Acids Res. 12 89-99

Maniatis, T., Fritsch, E. F., Sambrook, J. (1982). Molecular cloning. A laboratory manual. Cold Spring Harbor Laboratory, Cold Spring Harbor, N. Y

Mifflin, T. E., Bowden, J., Lovell, M. A., Bruns, D. E., Hayden, F. G., Groschel, D. H. M., Savory, J. (1987). Comparison of radioactive $\left({ }^{32} \mathrm{P}\right.$ and $\left.{ }^{35} \mathrm{~S}\right)$ and biotinylated probes for detection of cytomegalovirus DNA. Clin. Biochem. 20:231-235


son of fatty acid, protein, and serological properties distinguishing outer membranes of Pseudomonas anguilliseptica strains from those of fish pathogens and other pseudomonads. Int. J. system. Bact. 33: 1-8

Nishibuchi, M., Ishibashi, M., Takeda, Y., Kaper, J. B. (1985). Detection of the thermostable direct hemolysin gene and related DNA sequences in Vibrio parahaemolyticus and other Vibrio species by the DNA colony hybridization test. Infection Immunity 49:481-486

Nomura, J., Aoki, T (1985). Morphological analysis of lipopolysaccharide from gram-negative fish pathogenic bacteria. Fish Pathol. 20: 193-197

Rigby, P. W. J., Dieckmann, M. Rhodes, C., Berg, P. (1977). Labeling deoxyribonucleic acid to high specific activity in vitro by nick translation with DNA polymerase I. J. molec. Biol. 113: 237-251

Salyers, A. A., Lynn, S. P., Gardner, J. (1983), Use of randomly cloned DNA fragments for identification of Bacteroides thetaiotaomicron. J. Bact. 154: 287-293

Schubert, R. H. W. (1974). Genus II. Aeromonas Kluyver and van Niel 1936, 398. Bergey's manual of determinative bacteriology. William \& Wilkins Co., Baltimore, p. 345-348

Silhavy, T. J. (1984). Experiments with gene fusions, Cold Spring Harbor Laboratory, Cold Spring Harbor, N. Y., p. $137-139$

Southern, E. M. (1975). Detection of specific sequences among DNA fragments separated by electrophoresis. J. molec. Biol. 98: 503-507

Stave, J. W., Cook, T M., Roberson, B. S. (1987). Chemiluminescent responses of striped bass, Morone saxatilis (Walbaum), phagocytes to strains of Yersinia ruckeri. J. Fish Dis. 10: $1-10$

Wakabayashi, H., Kanai, K., Hsh Ta-C., Egusa, S. (1981). Pathogenic activities of Aeromonas hydrophila biovar hydrophila (Chester) Popoff and Veron, 1976 to fishes. Fish Pathol 15: 319-325

Manuscript first received: November 4, 1988

Revised version accepted: September 27, 1989 